\title{
KOKKUVÕTTES ERI SÕNALIIKIDE VAHEL
}

\author{
CARL ERIC SIMMUL
}

Annotatsioon. Artikkel käsitleb keelendi kokkuvõttes kasutuse põhjal nelja sõnaliigi, nimi-, tegu-, kaas- ja määrsõna funktsionaalseid kokkupuutealasid ja võimalikke ajaloolisi sõnaliikidevahelisi sildkontekste. Tegevusele viitava ühendverbi kokku võtma des-vormi ja selle tegevuse tulemusele viitava nimisõna kokkuvõte seesütlevavormi vormiline kokkulangemine ja funktsionaalsed ühisjooned teevad kaas- ja määrsõna päritolu kindlaksmääramise keeruliseks. Artikkel võrdleb keelendi kokkuvõttes määr- ja kaassõnalist funktsiooni nimisõna- ja tegusõnavormi omaga. Eri sõnaliikide kohaste funktsioonide võrdlus ja nendevaheliste seoste otsimine juhindub keelendi mõistelisest tähendusest ehk kokkuvõtmissündmuse komponentidest ning peab silmas nimi- ja tegusõna juurest kaas- ja määrsõna juurde viivaid tähenduse taandumise võimalikke teid. Kaas- ja määrsõna grammatiseerunud funktsioonid on käsitletavad nimisõna- ja tegusõnavormi taandunud mõistelise tähenduse põhjal. Võrdlemisi spetsiifiline, tulemuste käsitlemisele spetsialiseerunud kaassõnaline kasutus on kujunenud nimisõnavormi põhjal ning määrsõna tunduvalt avaramal kasutusalal on eristatavad ühelt poolt konversatsioonilise $d e s$-vormi põhjal kujunenud ja teiselt poolt nimi- või kaassõna põhjal kujuneda võinud funktsioonid.

Võtmesõnad: eesti keel, süntaks, morfosüntaks, sõnaliigid, sõnatähendus, grammatiseerumine, leksikaliseerumine

\section{Sissejuhatus}

Keelendit kokkuvõttes kasutatakse eesti kirjakeeles kokku ja lahku kirjutatud kujul nelja sõnaliigi kohaselt: nimisõna (lühikeses kokkuvõttes), tegusõna (eelnevat kokku võttes), kaassõna (kahe sõidu kokkuvõttes) ja määrsõnana (kokkuvõttes läks hästi). Keelend kokkuvõttes pakub muutuvate ja muutumatute sõnade seostesse ainulaadset sissevaadet: eesti keelest on raske leida teist keelendit, mille puhul need neli sõnaliiki samaviisi kokku puutuks. Artikkel kirjeldab keelendi tähenduse, kokkuvõtmissündmuse 
põhjal sõnaliikide kokkupuutealasid ja käsitleb osa neist võimalike grammatiseerumisteedena.

Õigekeelsussõnaraamat (ÕS 2013) ja seletav sõnaraamat (EKSS) esitavad nimisõna kokkuvõte, kuid sellist määr- ega kaassõna nagu kokkuvõttes pole esile toodud. Küll on nimisõna artiklis teiste hulgas näide, kus seesütlevakujulist vormi kokkuvõttes kasutatakse määrsõnana: „Kokkuvõttes läks kõik hästi (üldiselt).“ (ÕS 2013) Seletavas sõnaraamatus näitlikustab nimisõna ka kaassõnaline kasutus: „Meie sportlane oli kahe sõidu kokkuvõttes kolmas." (EKSS) Sõnaraamatud ei märgi, et niisugused kasutused võiksid olla midagi muud kui nimisõnavormid. Siin kirjutises käsitletakse aga määr- ja kaassõna omaette kasutusjuhtudena ning nende ja nimisõnavormi kõrvale seatakse ka des-vorm kokku võttes, et otsida vastust nelja keelendit hõlmavale uurimisprobleemile: kuidas on võinud kujuneda keelendi kokkuvõttes määr- ja kaassõnaline kasutusviis ning missugust osa on kujunemisloos täitnud nimisõna- ja tegusõnavorm? Kuigi sõnaraamatute põhjal jääb mulje, et kaas- ja määrsõnalist kasutust seostatakse funktsiooni ja ajaloo poolest nimisõnaga, juhib siinne kirjutis tähelepanu sellele, et vähemasti määrsõnast pole des-vorm funktsionaalselt sugugi kaugemal ega ole ka selle ajaloolise lähtekategooriana vähem tõenäoline.

Kirjutis põhineb kvalitatiivsel korpusuuringul. Võrreldakse keelendi kokkuvõttes eri sõnaliikide kohaste kasutusjuhtude tähenduslikke ja morfosüntaktilisi jooni ning otsitakse nende põhjal nimetatud juhtude ühiseid kontekste. Tänapäevast ühisosa võib omakorda käsitada ajaloolise ühelt funktsioonilt teisele ülemineku võimalusena. Töös esitatud näited pärinevad eestikeelsest veebilehtede korpusest etTenTen, eesti kirjakeele korpusest (KK) ja vana kirjakeele korpusest (VAKK). Mõni harvema nähtuse näide on leitud Google'i otsimootori abil, mispuhul on näite järel esitatud veebiaadress.

\section{Sõnavormide esmaesinemused}

Eesti keele korpustes leiduvast keeleainesest ei piisa vaatlusaluste sõnavormide vanuse ja ajalooliste seoste kindlakstegemiseks. Siiski võib des-vormi nimisõnavormist vanemaks pidada, kuna esimene on verbi ja teine sellesama verbi tuletise muutevorm. Nimisõna kokkuvõte esimene teadaolev ülestähendus pärineb Ferdinand Johann Wiedemanni sõnaraamatust ning määr- ja kaassõnaline kasutus on tõenäoliselt kujunenud 
XIX sajandi teisel poolel või XX sajandi algul. Korpuste kõige vanem des-vorm kokku võttes (näide 1) on pärit Andres Saali 1885. aasta jutustusest. Korpuste kõige vanem (kokku kirjutatud) määrsõnaline kasutus pärineb 1939. aastal avaldatud tekstist (näide 2) ja kaassõnaline kasutus 1950. aastate ajakirjandustekstist (näide 3). Kõige vanema seesütlevalise nimisõnavormi kokkuvõttes olen leidnud alles 1980. aastate ajakirjandustekstist, kus see esineb liitsõna põhiosana (näide 4).

(1) Kõik jõudu kokku wõttes sõudsiwad sõbrad kalda poole ning saiwad enne kose pääle jõudmist ka õnnelikult kaldasse. (VAKK, Saal 1885)

(2) Ja kokkuvõttes tegi nende mängki oma südantsalvava iluga kuidagi kurvaks. (KK)

(3) Viie etapi kokkuvõttes asus suursõidu liidri kohale P. Davidjan (,Dünamo"). (KK)

(4) Süüdistuskokkuvõttes märgitakse, et vandenõu organiseerijaks oli Kehar Singh. (KK)

\section{Keelendite grammatilisus}

Üks keelendi kokkuvõttes kasutuses varieeruvaid nähtusi on grammatilisus. Peter Harderi ja Kasper Boye (2011: 60) määratluse järgi on grammatilisus diskursiivne teisejärgulisus: grammatiline keelend talitleb teise keelendi tagaplaanil, väljendades teise tähenduse suhtes kõrvalist tähendust. Määrja kaassõna kokkuvõttes on kujunenud täistähendusliku nimisõna- või tegusõnavormi uues, teisejärgulises funktsioonis kasutamise tulemusel.

Osa täistähendusliku keelendi põhjal kujunenud täistähenduseta keelendeid on käsitatavad pigem pragmaatilise kui grammatilisena ning nende kujunemist võib käsitleda pragmatiseerumisena. Eelkõige puudutab see keelendeid, mida nimetatakse modaal- ja diskursusepartikliteks. Vähemalt osa funktsioonide järgi kuulub nende hulka ka määrsõna kokkuvõttes. Gabriele Diewald (2011: 457) on aga selgitanud, et pragmaatiliste keelendite kujunemine ei erine millegi poolest traditsioonilises mõttes grammatiliste keelendite kujunemisest. Seepärast kasutatakse keelendi kokkuvõttes funktsioonide kujunemise käsitlemisel (üld)terminit grammatiseerumine.

Kujul kokkuvõttes esinevate keelendite funktsionaalseid erinevusi käsitletakse semantika põhjal. See, et vaadeldavad keelendid lähtuvad 
ühendverbist kokku võtma, annab nende tähendusele sarnase võrdlusaluse, kokkuvõtmissündmuse, kus saab eristada nelja põhikomponenti: 1) kokkuvõtmistegevus, 2) kokkuvõtmise tegevussubjekt ehk kokkuvõtja, 3) kokkuvõtmise tegevusobjekt ehk see, mida kokku võetakse, ja 4) kokkuvõtmistulemus. Keelendi kokkuvõttes kasutust käsitletakse kokkuvõtmissündmuse põhjal. Alustatakse põgusa ülevaatega nimisõnavormist, seejärel käsitletakse pikemalt des-vormi. Seejärel tulevad vaatluse alla määr- ja kaassõna ning keelendite kokkupuutealad.

\section{Nimisõna kokkuvõte seesütlevavorm}

Kokkuvõte on ühendverbist kokku võtma tuletatud nimisõna. Asjaomase $e$-tuletiste malli järgi on saadud nii teo-, vahendi- kui ka tulemusnimetusi (Kasik: 272). Viimaste hulka kuulub ka nimisõna kokkuvõte, mis väljendab kokkuvõtmistegevuse tulemust.

EKSSis on esitatud sõna kokkuvõte kaks põhitähendust: 1) millegi lühike, ainult kõige tähtsamat sisaldav esitus (nt artikli kokkuvõte, teose sisu lühikene kokkuvõte) ja 2) mitmesuguste andmete või asjaolude põhjal saadud tulemus (nt valimistulemuste kokkuvõte, esimese veerandaasta kokkuvõte).

Siin töös kasutatakse veidi kohandatud jaotust: kokkuvõte on 1) teksti sisu kokkuvõtmise tulemus või 2) ajavahemiku sündmuste või nende tulemuste kokkuvõtmise tulemus. Esimest tähendust ilmestab näide 5.

(5) Ei ole mõtet iga viite juurde arutelu loota .. eriti kui lühikeses kokkuvõttes on ka viiteid minu enda kirjutatule. (etTenTen)

Tüüpiline nimisõnafraas vormiga kokkuvõttes talitleb lauses kohamäärusena, viitab mõne nähtuse põhisisu sõnastamise tulemusel valminud tekstile ja väljendab info asukohta. Vaadeldud materjali põhjal otsustades kasutatakse nimisõnavormi tunduvalt vähem kui samasuguse kujuga des-vormi, määr- ja kaassõna.

\section{Tegusõna kokku võtma des-vorm}

Ühendverb kokku võtma viitab millegi kompleksse koondamisele osade ühendamise teel. EKSS eristab ühendverbi kolme põhitähendust (millest ühel on kaks alltähendust): 
1) kedagi või midagi ühte rühma või kohta kokku koguma (nt mehi, kompse kokku võtma).

Selle rühma all on eraldi esile toodud jõu- ja energiavarude koondamisele viitav kujundlik alltähendus (nt jõudu, julgust kokku võtma, vt näide 1) ja kokkuarvutamise, liitmise alltähendus (arveid, sissetulekuid ja väljaminekuid kokku võtma);

2) kõige tähtsamat lühidalt sõnastama (nt oma seisukohti, muljeid, aastat kokku võtma);

3) end pingutama (end, ennast kokku võtma). des-vormi kasutatakse kõigis ühendverbi kokku võtma tähendustes, kuid võrdluses nimi-, määr- ja kaassõnaga väärivad lähemat vaatlust ainult kaks: teine põhitähendus 'sõnastama' ja esimese põhitähenduse teine alltähendus 'kokku arvutama'. Sõnastava kokkuvõtmise puhul (näide 6) öeldakse midagi nähtuse kui terviku põhjal. Arvutava kokkuvõtmise puhul (näide 7) liidetakse kokku mitu väärtust või tegurit.

(6) Olümpiahooaega kokku võttes tõdes Tamm, et sportlaste tulemused määravad edukuse. (KK)

(7) Kõhklejate pigem jaatavaid hoiakuid ning kindlalt jah-ütlejate hääli kokku võttes prognoosib Faktum, et rahvahääletuse tulemuseks on 72-78 protsendine toetus EL-iga liitumisele. (etTenTen)

des-vorm on käändeline verbivorm ja des-tarind talitleb lauses määrusliku konstruktsioonina: seeläbi vastab des-tarind tüpoloogilisele konverbitarindi kategooriale (vt nt Haspelmath 1995: 3; Ylikoski 2003: 222). Konverbitarindile omaselt on des-tarindil mitut laadi määruslikke tähendusi, misjuures konkreetse tarindi vahekord põhilausega selgub konteksti põhjal (vt Uuspõld 1966: 175-177; Erelt 2014: 215-219). Näites 6 esineval des-tarindil on ajatähendus. Tarindit parafraseerib nt ajalause Kui ta olümpiahooaega kokku võttis, siis tõdes .. Tarind näites 7 sarnaneb eelmisega, kuid arvutava kokkuvõtmise puhul tõuseb selgemalt esile vahendi tähendus: n-ö arvutustehet kujutav des-tarind seostub tehte vastust väljendava põhilausega nagu vahend tulemusega.

Konverbitarindi kategooriale omaselt esineb kaht tüüpi des-tarindeid: ühtede tegevussubjekt on tarindis väljendatud, eksplitsiitne, ja teiste oma väljendamata, implitsiitne (vt Haspelmath 1995: 10; Plado 2015: 315). Vormiga kokku võttes des-tarindite tegevussubjekt on implitsiitne ning ühtib näidetes 6-7 põhilause tegevus- ja grammatilise subjektiga, 
mis ongi des-tarindile omane (täpsemalt nt Uuspõld 1966: 84-85; Plado 2015).

Näidetes 5-7 esinevad määr- ja kaassõna kokkuvõttes lähtekategooriana kaalumist väärivad keelendid oma tüüpilisel kujul. Selliseid vorme on keeruline määr- ja kaassõnaga üheti seostada. Järgmisena tulevad vaatluse alla vähem tüüpilised - grammatilisemad des-tarindid, mil on määrsõnaga rohkem ühist. Märgata võib seaduspära, et keelendite sarnasus kasvab sedamööda, kuidas nõrgeneb des-vormi seos argumentstruktuuri, tegevussubjekti ja tegevusobjektiga.

\section{6. des-vormist määrsõna poole}

Kui näidetes 6-7 esitatud des-tarindite tegevussubjekt ühtib põhilause omaga, siis järgmiste vaadeldavate tarindite tegevussubjektina kerkib esile kõneleja või üldisik. Näites 8 on des-tarindi tegevussubjekt kõneleja ja kirjutaja ühes isikus. Näites 9 on tarindi tegevussubjektina mõistetav des-tarindi põhilause refereeritud autor Kallas.

(8) Esimest setti kiiresti kokku võttes hakkab esmapilgul silma Kanepi kindlus oma servil. (etTenTen)

(9) Nüüd ütleb Kallas, et kõiki valitsussektori kulutusi (kaasa arvatud sotsiaalkulud) kokku võttes on juba juuni lõpuks puudu koguni 2,5 miljardit. (etTenTen)

des-vormi seos kõneleja ja üldisikuga ei piirdu vormiga kokku võttes. Näiteks selsamal võttes-vormil esineb selline seos koos mitme teise laiendiga: arvesse võttes, midagi aluseks võttes, millegi järgi võttes, eraldi võttes, üldiselt võttes; mõistusega, loogiliselt, objektiivselt, ratsionaalselt jne võttes. Niisuguste tarindite abil suhestatakse põhilause sisu kõneleja tegevuse või hoiakuga. Helen Plado (2010: 259) on nimetanud nende tarinditega (muu seas) samasugust funktsiooni täitvaid $d a$-infinitiivse öeldisverbiga tingimuslauseid konversatsiooniliseks. See määratlus sobib ka vaadeldavatele des-tarinditele.

Ka konversatsiooniline des-tarind seostub põhilausega nagu tegevus tulemusega: näites 8 väljendab põhilause esimese seti sõnastava kokkuvõtmise ja näites 9 kulutuste kokkuarvutamise tulemust. Selle semantilise seose varal pakub konversatsiooniline tarind vastuvõtjale pragmaatilist sissejuhatust põhilause sisusse. Suhtlustasandile viitav konversatsiooniline 
tarind asub põhilausest funktsionaalselt kaugemal, on diskursiivselt teisejärgulisem ja ühtlasi grammatilisem (vt ptk 3) kui põhilausega samasubjektiline tarind. Peale seose tegevussubjektiga erineb osa kokku võttes -tarindeid tüüpjuhust ka tegevusobjektiga seostumise poolest. Kui kõiki seni vaadeldud tegevusobjekte väljendab des-vormi laiendav objekt, siis järgmisena vaadeldavate konversatsiooniliste tarindite tegevusobjektid on implitsiitsed, mõistetavad konteksti põhjal.

(10) Väga lühidalt kokku võttes on NATOga ühinemist vaja, et osaleda Alliansi kollektiivkaitsestruktuuris. (etTenTen)

(11) Peale palga pakutakse töökohavahetajatele ka muid materiaalseid hüvesid, mis kokku võttes annavad päris arvestatava palgalisa. (etTenTen)

Näites 10 võib sõnastavale kokkuvõtmisele viitava des-tarindi tegevusobjekti mõista nii varasema konteksti kui ka põhilause põhjal. Näites 11 esitatud des-tarindis arvutatakse kokku materiaalseid hüvesid, millele viitab viimati põhilause subjekt mis. Näidetes 10-11 esinevate tarindite kokkuvõtmissündmus oleneb tervenisti kõneolukorrast: tegevussubjekt on konversatsiooniline, tegevusobjekt on mõistetav konteksti põhjal, kokkuvõtmistulemust väljendab põhilause.

Näidetes 8-11 esinevate des-vormide seost argumentidega pole vormistatud. Määrsõna juurde on siit väike samm. Allpool tulevad vaatlusele kontekstid, kus määrsõna kokkuvõttes on käsitatav implitsiitse tegevusobjektiga konversatsioonilise des-tarindi järgmise astmena, mis on kaotanud tegevuslikkuse ja seose argumentidega.

\section{7. des-vormi ja määrsõna kokkupuuteala}

des-vormi ja määrsõna kokkupuutepinna toovad ilmekalt esile eesti kirjakeele korpuse esimesed kokku võttes -vormid. Korpuse kolmest 1950. aastate eelsest vormist väärib tähelepanu üks, mis pärineb 1900. aastate ilukirjandusest (näide 12).

(12) Kohe esimene mõte käis jälle käsikirja peale, aga nüüd oli minu mõistuse ees see asi juba märksa selgem ja ma võisin kokku võttes ühe otsuse teha. (KK)

Näites 12 esinev keelend kokku võttes on kirjutatud lahku, kuid selles kontekstis ei kerki esile des-vormi implitsiitset tegevusobjekti. Vormi kõige tõenäolisem tõlgendus näib määrsõnaline: seega oleks tegu vanima 
näitega määrsõnast kokkuvõttes. des-vormi ja määrsõna seosele osutab ühine kontekst, mille toovad esile kolm 1950. aastate ajakirjandustekstides esinevat lahku kirjutatud vormi (näited 13-15).

(13) Need on kokku võttes tallinlaste eelseisvad ülesanded .. (KK)

(14) Kokku võttes, käsiteldud teos on suurel määral ebaõnnestunud ega täida täielikult oma ülesannet .. (KK)

(15) Selline on kokku võttes Valentin Katajevi jutustuse „Mina, töörahva poeg" sündmustekäik. (KK)

Näidetes 13-15 esinevaid keelendeid saab tõlgendada nii tegevust väljendava des-vormina kui ka mittetegevusliku määrsõnana. Mõlemat tõlgendust võimaldav kontekst peab vastama mõnele tingimusele. Vormil kokku võttes pole laiendeid: määrsõnal ei saa neid olla, des-vormil ei pea olema. des-tarindi kohase tõlgenduse korral saab implitsiitse tegevusobjektina tõlgendada kontekstis kõneks olevat teemat. Näites 13 on sellena tõlgendatav nimisõnafraas tallinlaste eelseisvad ülesanded, näites 14 eespool räägitu, näites 15 alusena talitlev nimisõnafraas peasõnaga sündmustekäik. Seos tegevussubjektiga on vormide tegevusliku tõlgenduse korral konversatsiooniline, määrsõnalise tõlgenduse korral see aga puudub.

Vormi kokku võttes des-tarindi ja määrsõna kohane tõlgendus erinevad tähenduse poolest. des-tarind toob esile kokkuvõtmise kui konversatsioonilise sõnastamistegevuse, määrsõna fookus on aga ahenenud laiendatava lause iseloomustamisele: lause käsitleb teemat kokkuvõtlikult, st üldistavalt. des-tarindis väljenduva dünaamilise tegevuse asemel väljendab staatilisem määrsõna teemakäsitluse omadust.

Näidetes 13-15 esile tulev kontekst ilmestab võimalikku reanalüüsikohta, kus kokkuvõttes on võinud väljuda tegusõna paradigmast ja määrsõnastuda. Sel juhul oleks määrsõna tekkinud nii, et taandus desvormi kokku võttes tõlgenduslik side tegevussubjekti, tegevusobjekti ja ühtlasi kokkuvõtmise kui tegevusega. Niisugusel kujunemiskäigul on ühisjooni Ellen Uuspõllu (2001) käsitletud alates- ja võrreldes-vormide kaassõnastumisega: subjektiseose kaotanud des-vormid hakkavad tegevuse asemel väljendama suhet. Seejuures on keelendite vahel kaas- ja määrsõna kohased erinevused: kui laiendi säilitanud alates ja võrreldes-vormid seostavad omavahel laiendit ja laiendatavat keelendit, siis laienditeta kokkuvõttes seostub süntaktiliselt ainult ühe, laiendatava keelendiga. 
Laienditeta konversatsioonilise des-vormi kasutuskontekstides on tänapäeval rööpse võimalusena kasutatav ka määrsõna. Näidetes 16-17 on konversatsiooniline des-vorm tegevusliku tõlgenduse korral põhilausega samasubjektiline, mis aga ei tähenda, et kokkuvõttes ei võiks esineda määrsõnana. Vormi laiendav viisimäärus - nagu näites 18 - tõstab aga esile tegevusliku tõlgenduse, hoolimata pigem määrsõnaga seotud kokkukirjutusest.

(16) Kokku võttes tuleb nentida, et enne majandusaasta aruande analüüsi ei saa laululava linnalt raha juurde. (etTenTen)

(17) Kokkuvõttes tuleb tõdeda, et Dreyeri näol oli tegemist äärmiselt toimeka ja mitmekülgsete huvidega inimesega. (etTenTen)

(18) Kõik see tähendab lühidalt kokkuvõttes üht - palgaarmee pooldajad, eeldusel, et nad on teema endale enam-vähem selgeks teinud, kuulutavad valjult ja varjamatult .. (etTenTen)

(19) Kui linnatihane kasvatabki üles vähem poegi kui metsatihane, siis õnnestub tal ehk pesitseda rohkem kordi. Kokku võttes võib tema järglaste arv olla suurem. (etTenTen)

Kui seni esitatud näited des-vormi ja määrsõna ühise konteksti kohta vastavad sagedamini esineva sõnastava kokkuvõtmise tüübile, siis näide 19 ilmestab n-ö kokkuarvutavat ühiskonteksti. des-tarindina tõlgendades viitab keelend eelnevast kontekstist tulenevate tegurite kokkuarvutamisele ja põhilause selle tulemusele. Määrsõnalise tõlgenduse korral on kokkuarvutaja roll taandunud ning laiendatav lause ei tõlgendu enam tegurite kokkuarvutamise tulemusena, vaid nende eneste kombineerumise või koosmõju tulemusena.

\section{Määrsõna kokkuvõttes}

Praeguseks on määrsõna levinud mitmesugusesse konteksti, kuid ühisjooned konversatsioonilise des-tarindiga on siiski olemas. Tänu funktsiooni sarnasusele sobib des-tarind määrsõna funktsiooni kirjeldamise aluseks. Näidetes 20-24 on mõni määrsõna kasutusviis, mispuhul võib täheldada rohkem või vähem taandunud seoseid kokkuvõtmissündmuse komponentidega. Üldiselt võib esitada järjekorra: seose kokkuvõtjaga on määrsõna kaotanud; seos kokku võetavaga varieerub tugevuse poolest; kõige tugevam on seos kokkuvõtmise tulemusega, mida väljendab määrsõna laiendatav keelend. 
(20) Lavastaja on kokkuvõttes üks donjuan, kes armastab vallutada uut materjali. (etTenTen)

(21) Kui aga teha väike sissemakse ja valida pikem periood, läheb ost kokkuvõttes palju kallimaks. (etTenTen)

(22) Kokkuvõttes tuli album välja alles 1990. aastal. (etTenTen)

(23) Paralepas läinud pühapäeval peetud 3. rattakrossil oli Andrus Tammistus finišis küll parim läänlane, kuid jäi kokkuvõttes teiseks tallinlase Igor Tarassovi järel. (etTenTen)

(24) Loodan, et jääte õhtuga kokkuvõttes siiski rahule. (etTenTen)

Näidetes 20-21 on täheldada konversatsioonilise kokkuvõtmissündmuse põhja: lause näites 20 kujutab endast lavastaja elukutse sõnastava kokkuvõtmise tulemust. Näide 21 põhineb aga arvutaval kokkuvõtmisel: põhilause väljendab tingimuslause osalausete (kui tegevusobjektide) kombineerimise tulemust.

Näidetes 22-24 on seos konversatsioonilise kokkuvõtmissündmusega nõrgem. Näites 22 väljendab määrsõna kokkuvõttes sisaldav lause eespool mainitud tegurite tagajärge ning näites 23 läänlaste ja mujalt pärit võistlejate koosarvestamise tulemust. Näites 24 esitatud lause on lähemal sõnastavale kokkuvõtmisele. Erinevalt konversatsioonilisest des-tarindist ei väljenda määrsõna kokkuvõttes aga mitte kõneleja, vaid lause semantilise kogeja (mitmuse teise isiku) vaatekohta.

Määrsõna kasutuses saab eristada kaht, sõnastaval ja arvutaval kokkuvõtmisel põhinevat joont. Sõnastava kokkuvõtmise tulemusest on määrsõna puhul saanud üldistus: määrsõna laiendab teema või nähtuse üldistust. Arvutaval kokkuvõtmisel põhinev määrsõna osutab tulemuslikkusele.

Tänapäeva kasutuste põhjal ei hakka aga silma määrsõna ja samakujulise nimisõnavormi vahelisi sildkontekste. Peamiseks põhjuseks võib pidada seda, et nimisõnavormi kasutatakse kitsas, üksnes teksti tähenduses. Kuigi määrsõnalise ja nimisõnalise kasutuse vahel pole märgata vahetut kokkupuuteala ega võimalikku otsest üleminekuala, on mõlema sõnaliigi puhul näha ühisosa keelendi kaassõnalise kasutusega, mis tuleb vaatluse alla järgmisena. 


\section{Kaassõna kokkuvõttes}

Kaassõna kokkuvõttes täidab ühest küljest üsna kitsast funktsiooni. Teisest küljest asub see keelendi kokkuvõttes funktsionaalses keskmes: sel on arvestatav kokkupuutepind nimisõna, tegusõna ja määrsõnaga.

Kaassõna kokkuvõttes seostab sündmusi ja ajavahemikke nende sisuga, enamasti tulemustega. Sündmusi ja ajavahemikke väljendavad kaassõna laiendid ning nende sisu kajastab kaassõnatarindiga lause. Kaassõna kokkuvõttes abil väljendatava konteksti moodustavad mitu ühesugust üksust (näide 25) või ka ainult üks kompleksne üksus (näide 26). Nagu kaassõnade puhul üldiselt, ei esine kaassõnal kokkuvõttes omadussõnalisi ega muid modifitseerivaid laiendeid (vt Veismann, Erelt 2017).

(25) Ta edestas suurslaalomis kahe sõidu kokkuvõttes prantslast Frederic Covilid 0,13 sekundiga. (KK)

(26) Esimese kvartali kokkuvõttes tehti Tallinnas korteritega tehinguid 1297 ja keskmiseks hinnaks kujunes 13646 krooni ruutmeetri kohta. (etTenTen)

Samamoodi nagu arvutavale kokkuvõtmisele viitav des-tarind talitleb kaassõnatarind määrusena tulemusi käsitlevas lauses. Sealjuures on tarindite vahel põhimõtteline erinevus: kui des-tarindi põhilause väljendab tarindi tegevusobjektide kokkuvõtmise tulemust, siis kaassõnatarindiga lause väljendab laiendite - ajavahemike ja sündmuste - endi tulemust. Sisuline seos valitseb kaassõnatarindi laiendite (kui ajavahemiku või sündmuse) ja ülejäänud lause (kui tulemuse) vahel ning kaassõna kokkuvõttes funktsioon on selle seose väljendamine.

Kaassõna kokkuvõttes funktsioneerib teiste tähenduste, sündmuse ja tulemuse vahel ja tagaplaanil. Ühtlasi täidab kaassõna grammatilistele keelenditele tunnuslikku funktsiooni: suhestada laiendatavat keelendit millegi muuga (vt Diewald 2011: 454). Kaassõna kokkuvõttes suhestab sündmust ajavahemikuga või tulemust sündmusega.

Nagu eespool (ptk 4) mainitud, on nimisõnavorm kokkuvõttes kasutusel kahes kitsas, 1) tekstide ja 2) sündmuste-ajavahemike kokkuvõtmise tulemuse tähenduses. Viimane on käsitatav kaassõna kokkuvõttes lähtekonstruktsioonina. Nimi- ja kaassõna vahekorda aitavad selgitada näited 27-28.

(27) Aastakokkuvõttes on välja toodud juhtkonna efektiivne tegutsemine ja optimistlik meelelaad. (sysadminnid.tumblr.com) 
(28) Terve Nord Pooli süsteemihind oli eelmise aasta viimasel kuul 31,79 eurot ning aasta kokkuvõttes 26,91 eurot megavatt-tunnist. (majandus24.postimees.ee)

Näide 27 sisaldab nimisõna seesütlevavormi, mis viitab ajavahemiku sündmusi ja tulemusi käsitlevale tekstile. Näide 28 ilmestab nimisõnavormist tunduvalt sagedamat kaassõnatarindit, mispuhul kokkuvõttes ei osuta enam iseseisvale nähtusele (tekstile). Kaassõnatarindi funktsionaalne fookus on nihkunud laiendi abil väljendatud ajavahemikule ja selle seosele laiendatavas lauses väljendatud tulemusega.

Sõnavormi kokkuvõttes kaassõnastumist võib pidada süntaktiliselt tingituks (vt Kasik 2015: 408): määrusena talitlev seesütlevavorm on saanud grammatilisema (teisejärgulisema) tähenduse. Nimisõna käändevormi leksikaliseerumine ongi kaassõnade põhiline tekkeviis (Karelson 2005: 63; Kasik 2015: 404).

Peale nimisõna on kaassõnal kokkuvõttes kokkupuutepind ka määrsõnaga, seda ilmestavad näited 29-32.

(29) Kuigi tehingute arv on oluliselt langenud, ei avaldanud see aasta kokkuvõttes märkimisväärset mõju keskmisele tehingu väärtusele. (etTenTen)

(30) Kokkuvõttes tõusis veetariif 2001-2005 esialgu fikseeritud 30\% asemel vaid $16,2 \%$ võrra. (etTenTen)

(31) Tartu Ülikooli peatreeneri Indrek Visnapuu sõnul näitab venelaste tugevust nende Euro-Challenge võit Samara üle kahe mängu kokkuvõttes. (etTenTen)

(32) Laupäevases kohtumises näitas meeskond väga head minekut - juba esimene veerand võideti 15 punktiga ja kokkuvõttes teeniti korralik 94:66 võit. (etTenTen)

Kaas- ja määrsõna puutuvad kokku lausetes, kus käsitletakse mingi aja jooksul toimunud sündmusi (näited 29-30) või nende tulemusi (näited 31-32). Kaassõnatarindis (näited 29, 31) toob tulemuste ajalise konteksti esile laiend. Määrsõna (näited 30, 32) ajalisele kontekstile ei viita, vaid toonitab lihtsalt, et lausung väljendab tulemust. See, mille tulemusega on tegu, võib selguda lausekonteksti (näide 30) või asjatundmise (näide 32) põhjal.

Funktsionaalne kokkupuude kaassõnatarindiga tõstab (des-vormist kujunemise kõrval) esile veel kaks määrsõna kujunemise võimalust: see on võinud kujuneda kaassõnatarindi või nimisõnafraasi põhjal. 
Kaassõnatarindi põhjal oleks määrsõna kujunenud kontekstist selguvate laiendite ärajäämise kaudu, n-ö elliptilise kaassõnafraasina (vt Veismann, Erelt 2017). Nimisõnafraasi põhjal kujunenud määrsõna oleks aga erinevalt kaassõnatarindist kujunenud ilma kokku võetud nähtusele osutava täiendita nimisõnavormi põhjal. Sama sõnavormi talitlemine koos nimisõnaga kaassõnana ja ilma nimisõnata määrsõnana pole eesti keeles ebatavaline (vt nt Habicht 2000: 22; Karelson 2005: 62; Veismann, Erelt 2017).

Tänapäeval aga ei näi nimisõnavormi ja määrsõna kokkuvõttes vahel olevat funktsionaalset kokkupuutepinda. Sündmuste või ajavahemike kokkuvõtmise tulemuse tähenduses esinevatel harvadel nimisõnavormidel on alati sündmusele viitav täiend, mis on enamasti vormiga kokkuvõttes kokku kirjutatud (nagu näidetes 4 ja 28). Keelendi kokkuvõttes tänapäevase kasutuse põhjal on seega näha kaassõna ja nimisõnavormi kokkupuuteala, kuid mitte määrsõna ja nimisõnavormi kokkupuudet. Igal juhul oleks nimisõnavormi ja kaassõnatarindi põhjal kujunenud samasugune tulemuslikes kontekstides esinev määrsõna. Järgnevalt lähtutakse tulemuslikes kontekstides esineva määrsõna käsitlemisel funktsionaalse sarnasuse alusel kaassõnatarindist, välistamata seda, et ajalooliselt on see kujunenud nimisõnafraasi põhjal.

\section{0. des-tarindi ja kaassõnatarindi põhjal tekkinud määrsõna}

Määrsõna kokkuvõttes tekkimise selgitamiseks piisaks kas des- või kaassõnatarindist: emma-kumma keelendi põhjal kujunes samal viisil kasutatav määrsõna, mis liikus edaspidi ka teistsugustesse, sh teise tarindi kohastesse kontekstidesse. Üks ei välista teist: des-vorm ja kaassõna on võinud mõlemad määrsõnastuda.

Määrsõna kokkuvõttes kasutuses leidub ühisjooni kolme võimaliku lähtekeelendiga: 1) sõnastavat ja 2) arvutavat kokkuvõtmist väljendava implitsiitse tegevusobjektiga konversatsioonilise des-tarindi ning 3) kaassõnatarindiga. Allpool tuleb vaatlusele, kuidas kokkuvõtmissündmuse osad (tegevussubjekt, tegevusobjekt ja tulemus) esilduvad eri lähtekeelendite kohaselt kasutatud määrsõnade puhul erineval määral.

(33) Kokkuvõttes võiks öelda, et underground skene on Riias nõrk. (etTenTen) 
(34) .. siis on sportimisega saavutatav vaimne ja kehaline vormisolek ning parem tervis vaieldamatult inimese toimetuleku ja töövõime, kokkuvõttes edukuse alus. (etTenTen)

(35) Nädalavahetuse Göteburgis superfinaalturniiriga lõpule jõudnud Euroopa Noorte Korvpalliliiga U17 vanuste turniiril võitis Salva/Tartu Ülikool kokkuvõttes viienda koha. (etTenTen)

Konversatsiooniline des-tarind seab kokkuvõtja ossa kõneleja või üldisiku, kaassõnatarind kokkuvõtjat esile ei too. Määrsõna kokkuvõttes kasutuses saab eristada kontekste, kus kokkuvõtja kui kõnealuse teema käsitleja on esil (näide 33) või olemas (näide 34), ja kontekste, kus kokkuvõtja roll esile ei tõuse (näide 35). Kokkuvõtja on käsitlejana esil üldistavates-arutlevates jms kontekstides, tagaplaanil aga sündmuste n-ö objektiivseid tulemusi esitavates kontekstides.

Kokku võetav nähtus on implitsiitse tegevusobjektiga des-tarindite puhul mõistetav konteksti põhjal. Sõnastava tarindi puhul on tegevusobjekt pragmaatiliselt esilduv teema. Näites 33 oleks des-tarindi korral tegevusobjekt eespool öeldu või põhilause teema. Arvutava tarindi implitsiitsed tegevusobjektid on konkreetsed põhilause keelendid: näites 34 (des-tarindi korral) inimese toimetuleku ja töövõime.

Kaassõnatarindi tähendusliku struktuuri eritlemisel võib toetuda nimisõnafraasile, mille täiend viitab kokku võetud nähtusele. Nt konstruktsioonis Võistluste kokkuvõttes on märgitud, et .. viitab nimisõnavorm kokkuvõttes võistluste kokkuvõtmise tulemusele. Kuna kaassõnatarindi laiend põhineb nimisõnafraasi täiendil, võib öelda, et kaassõnatarindis on säilinud varasem kokkuvõtmistegevuse tegevusobjekt, mis ei tõlgendu aga enam tegevusobjektina.

Määrsõna kokkuvõttes seos tegevusobjektiga on vormilt kadunud ja võib olla ka tõlgenduslikult hääbunud. Tõlgenduslik seos oleneb kontekstist, põhiliselt sellest, kas keelendit, mida kokkuvõttes laiendab, saab mõista kokkuvõtmistulemusena.

Sõnastava ja arvutava konversatsioonilise des-tarindi puhul kajastab kokkuvõtmistulemust põhilause: keelekasutaja võtab teema oma sõnadega kokku ja selle tulemus on tema öeldu. Kaassõnatarindiga lauses kajastuv tulemus pole seevastu mõistetav mitte (kokkuvõtmis)tegevuse tulemusena, vaid sündmuse või ajavahemiku otsese n-ö objektiivse tulemusena. Lause või fraasi kujul esitatud tulemuse (üld)laiendina talitlev määrsõna 
kokkuvõttes võib laiendada nii millegi kokkuvõtmise tulemust (näited 33-34) kui ka sündmuse otsest tulemust (näide 35).

Määrsõna kokkuvõttes kasutuste seas saab eristada des-tarindi ja kaassõnatarindi kohaseid kasutusi. des-tarindile vastavates kontekstides (näited 33-34) esildub keelekasutaja kui kokkuvõtja ning määrsõna laiendatav keelend väljendab mingi teema või asjaolude mõttelise kokkuvõtmise tulemust. Kaassõnatarindile vastavas kontekstis $(30,32,35)$ kokkuvõtmise tegevussubjekti ega tegevusobjekti ei esildu ning määrsõna laiendatav keelend on mõistetav sündmuse või ajavahemiku otsese tulemusena.

Määrsõna kokkuvõttes kahe kirjeldatud konteksti vahel on tänapäevases kasutuses sujuv üleminek. Siiski on kontekstid üsna erinevad, et võtta võimalusena arvesse määrsõna kujunemise kaht juhtumit: üldistav-kokkuvõtlik kokkuvõttes konversatsioonilise des-tarindi põhjal ja tulemuslik kokkuvõttes kaassõnatarindi põhjal. Esimese tarindi määrsõnastumine võis toetada teise tarindi kohase määrsõna kujunemist.

Korpuste kõige vanemad määrsõna kokkuvõttes kasutusjuhud sarnanevad rohkem des- kui kaassõnatarindi kasutusega: määrsõna laiendab nähtuse üldistava kokkuvõtmise tulemust. See kehtib nii kokku (näide 2) kui ka lahku (näited 13-15) kirjutatud keelendite kohta. Ka vanus räägib kaassõnast ja nimisõnavormist vanema des-vormi kasuks.

Seni vaadeldu põhjal näib määrsõna kokkuvõttes kõige tõenäolisem lähtekeelend olevat des-tarind. Korpuste järgi sarnaneb määrsõna kõige vanem ja ka tänapäeval kõige sagedam üldistav funktsioon enim des-tarindiga. Määrsõna kasutus tulemuslikes kontekstides, kus see puutub kokku kaassõnatarindiga, on ilmselt hilisem ja harvem nähtus. Kõige suuremaks küsimuseks jääb määrsõna ajalooline vahekord nimisõnafraasiga. Nagu üheksanda peatüki lõpus märgitud, on üks nimisõnavormist määrsõnaks ülemineku võimalus kaassõnatarindi analoogia põhjal. Järgmises peatükis tuleb keelendi lühikokkuvõttes kaudu esile veel üks nimisõnavormi ja määrsõna kokkupuutepind ja võimalik sildkontekst.

\section{Lühi-, vahe-, üld- ja lõppkokkuvõttes}

Keelendit kokkuvõttes kasutatakse koos nelja täiendosaga: lühi-, vahe-, üld- ja lõppkokkuvõttes. Täiendosad täidavad täpsustavat (lühi-, vahe-, üld-) ja tugevdavat (üld-, lõpp-) funktsiooni. Komplekssemad kujud on kasutusel nimi-, kaas- ja määrsõnana ning nende funktsioonid pakuvad 
sõnaliikide seostesse täiendavat sissevaadet. Täiendosaga keelendite funktsioonide kujunemisloo kindlaksmääramine on probleemne. Nende kasutusele tuleku ajaks olid eeldatavasti olemas nii kaas- kui ka määrsõna kokkuvõttes. Seetõttu võib täiendosaga keelendite kasutus järgida vormi kokkuvõttes mitmekesise kasutuse eeskuju: nt võib vormi vahekokkuvõttes kaassõnaline kasutus põhineda kaassõnal kokkuvõttes, eeldamata seda, et nimisõnavorm vahekokkuvõttes on omakorda grammatiseerunud.

Sõnastava-üldistava funktsiooniga keelendit lühikokkuvõttes kasutatakse nimi- ja määrsõnana, kuid mitte kaassõnana, mis esineb ainult tulemuslikus kontekstis. Nimisõnana viitab lühikokkuvõttes teksti kokkuvõtmise tulemusele, tüüpiliselt tekstile, kuid ka seisundile (näide 37). Keelendi lühikokkuvõttes kasutus toob esile nimi- ja määrsõna üleminekuala - seisundimääruse funktsiooni-, mis keelendi kokkuvõttes funktsioonide seas esile ei kerkinud. Seisundimääruse funktsioonis oleneb nimi- ja määrsõna vahekord sellest, kas keelend viitab nähtuse seisundivormile või käsitlemise laadile. Keelendi lühikokkuvõttes kasutust ilmestavad näited 36-39.

(36) Seepärast ei pööranud ma oma ülevaates artikli sellele küljele erilist tähelepanu, nagu jääb see suhteliselt tagaplaanile ka autori enda kirjutatud lühikokkuvõttes. (etTenTen)

(37) Evolutsioonilugu kõlab rahvapärases lühikokkuvõttes teinekord nõnda, et ahv tuli puu otsast alla ja sai inimeseks. (etTenTen)

(38) Põgenik pöördub jälitaja poole pika kõnega, mille sisu lühikokkuvõttes on, et käes on aeg muutuda homo sapiensist millekski kõrgemaks. (etTenTen)

(39) Ehk lühikokkuvõttes - olen stand by režiimil. (etTenTen)

Näite 36 nimisõnavorm lühikokkuvõttes viitab lauses kohamäärusena talitlevale tekstile. Näite 37 nimisõnavormi kasutatakse seisundi, esinemisvormi tähenduses. Lühikokkuvõttes ei viita siin mitte kirja pandud tekstile, vaid evolutsiooniloo suusõnalisele esinemiskujule. Fraas on parafraseeritav mitme seisundimäärusega: .. lühikokkuvõttena, lühikokkuvõtte kujul või vormis.

Näite 38 keelendit lühikokkuvõttes saab tõlgendada kahel moel: nii kõne sisu esinemise kui ka esitamise vormina. Esinemisvormina on lühikokkuvõttes seisund, kõne sisu enda esinemiskuju. Sel juhul on see 
seisundimääruslik nimisõnavorm ja näites 37 esineva keelendi sarnane. Esitamisvormina on lühikokkuvõttes tõlgendatav keelekasutaja metakeelse märkusena: ta võtab kõne sisu kui nähtuse komplementlause abil lühidalt kokku. Sel juhul on lühikokkuvõttes määrsõna. Näite 39 keelend lühikokkuvõttes on selgelt määrsõna (täpsemalt modaaladverb). Teemakäsitlust iseloomustava üldlaiendina asub see kõneolukorra põhitähendusest nii kaugel, et pole laiendatava lause (määruslik) liige.

Nagu eespool mainitud, viitab nimisõnavorm harilikult tekstile ja talitleb kohamäärusena. Kuigi üleminek kohamääruselt kohakäändelisele seisundimäärusele on sujuv (EKG II: 91), jääb nimisõnavormi kokkuvõttes kasutatavus seisundimäärusena selle töö seisukohalt lahtiseks. Küsimus on siiski oluline: seisundimäärus kujutab endast nimisõnavormi ja määrsõna kokkuvõttes potentsiaalset sildkonteksti (nagu näidetes 37-38).

Erinevalt keelendist lühikokkuvõttes seostub vahekokkuvõttes sündmuste ja ajavahemike (vahe)tulemustega. Seda kasutatakse peamiselt nimi- ja kaassõnana ning vähem määrsõnana.

(40) Miks muidu rõhutab advokaat Raidla „Sõnumilehes“6 avaldatud ekspertiisi vahekokkuvõttes, et Vähi pöördus advokaadibüroo poole eraisikuna. (KK)

(41) Majandusaasta vahekokkuvõttes nenditi, et eelmisele perioodile jääb käesolev aasta kõvasti alla. (etTenTen)

(42) Turniiri vahekokkuvõttes on kindlalt juhtimas eelmise aasta Külaliiga meistermeeskond Õhust ja Armastusest. (etTenTen)

(43) MMist on veerand selja taga ja vahekokkuvõttes võib öelda, et hooaeg algas taas McLareni ülekaaluga .. (KK)

Näites 40 viitab vahekokkuvõttes nimisõnaliselt tekstile. Näites 41 esinevat keelendit vahekokkuvõttes saab tõlgendada nii nimisõna kui ka kaassõnana. Nimisõnalise tõlgenduse korral võib keelendit vahekokkuvõttes laiendada täiend (nt kiiruga tehtud), kaassõnalise tõlgenduse korral mitte. Näites 42 suhestab kaassõna vahekokkuvõttes võistlust otse (vahe)tulemusega. Näites 43 esinev määrsõna vahekokkuvõttes on käsitatav elliptilise kaassõnatarindina, mille laiend ( $M M$, hooaeg) on jäetud väljendamata.

Nimisõnavormid lühi- ja vahekokkuvõttes on sagedased võrreldes nii samakujulise määr- ja kaassõnaga kui ka nimisõnavormiga kokkuvõttes. Järgmisena vaadeldavaid keelendeid üld- ja lõppkokkuvõttes kasutatakse nimisõnana vähem. 
Spordi- ja teiste võistluste tulemuste käsitlemisel kasutatav keelend üldkokkuvõttes sarnaneb tulemusliku konteksti poolest keelendiga vahekokkuvõttes. Erinevalt viimasest kasutatakse seda aga ainult kaas- ja määrsõnana.

(44) Kuue ala üldkokkuvõttes (kavas oli veel kabe) kogusid Leedu ja Eesti võrdselt 3 kohapunkti. (KK)

(45) Üldkokkuvõttes muutub töö komplitseeritumaks ja pingelisemaks. (etTenTen)

Näites 44 on üldkokkuvõttes kasutusel kaassõnana. Keelendile iseloomulikult viitavad laiendid võistlussündmustele (mitte ajavahemikele). Näide 45 ilmestab keelendi määrsõnalist kasutust.

Ühtaegu kõige sagedamini ja sõnaliigi seisukohalt kõige piiratumalt - määrsõnana - kasutatakse neljast täiendosaga variandist keelendit lõppkokkuvõttes.

(46) See, kas nende räägitu meile meeldib või vastuvõetav on, ei ole lõppkokkuvõttes ju absoluutselt oluline. (etTenTen)

(47) Teine ja tegelikult lõppkokkuvõttes isegi usutavam põhjus on tegijate soov ennast puhtaks pesta neile osaks saanud süüdistustest. (etTenTen)

Kategoorilise ja intensiivistava keelendina lisab lõppkokkuvõttes tugevdava täiendsõna toel lausungile sisulist kaalu. Keelend seostub harvem kõnealuste asjaolude objektiivse lõpptulemusega ja sagedamini kõneleja tihti poleemilise subjektiivse arvamusega.

\section{Kokkuvõte}

Keelendi kokkuvõttes puhul puutuvad mitmeti kokku nimi-, kaas-, määrja tegusõna funktsioonid. Artiklis vaadeldi seda, kui tõenäoline on üks või teine sõnaliikidevaheline kokkupuutekoht ajaloolise sildkontekstina.

Tegusõnal kokku võtma ja sellest tuletatud nimisõnal kokkuvõte on kindel tähenduslik vahekord: nimisõna väljendab tegusõnaga väljendatava tegevuse tulemusel valminud teksti. Sõnade juhtumisi kokku langevat seesütleva- ja des-vormi ühendab vormiline ja funktsionaalne sarnasus. Mõlemad vormid talitlevad lauses kokkuvõtmistegevuse tulemusega seotud konteksti väljendava määrusena. Siiski on nimisõna- ja tegusõnavorm tänu tähenduse erinevusele sarnasteski kontekstides selgelt eristatavad keelendid. 
Nimisõna- ja tegusõnavormi kokkulangemine seab aga küsimuse alla kaas- ja määrsõna kokkuvõttes päritolu. Kitsama ja ühelaadilise funktsiooniga kaassõna grammatiline funktsioon on kujunenud nimisõna semantilise tähenduse põhjal. Kaassõna ajavahemikule või sündmusele viitav laiend vastab nimisõna täiendile.

Avarama kasutusalaga määrsõnal leidub funktsionaalseid kokkupuutekohti des- ja kaassõnatarindiga. Ehkki samakujulise nimisõnavormiga ei näi määrsõna tänapäeval vahetult kokku puutuvat, tulevad teiste keelendite, kaassõnatarindi ja keelendi lühikokkuvõttes põhjal nähtavale ka nimisõnavormi ajaloolise määrsõnastumise võimalused. Nõnda on määrsõna kokkuvõttes võinud kujuneda konversatsioonilise des-tarindi, elliptilise kaassõnatarindi, täiendita nimisõnafraasi või seisundimäärusliku nimisõnafraasi põhjal. Iga potentsiaalse lähtekonstruktsiooniga seostub vahetult ainult osa määrsõna funktsioone ja kasutuskontekste ning ühe lähtekonstruktsiooni grammatiseerumine ei välista teiste konstruktsioonide grammatiseerumist.

Keelendi kasutuses ilmnevaid sõnaliikide seoseid käsitleti keelendi tähenduse, täpsemalt kokkuvõtmissündmuse komponentide põhjal. Vaatluse all olid nimisõna- ja tegusõnavormist kaas- ja määrsõna juurde viivad tähenduse taandumise ja funktsiooni teisejärguliseks muutumise teed. Näiteks üks des-vormist kokku võttes määrsõna kokkuvõttes juurde viiv tee seisneb kokkuvõtmistegevuse argumentstruktuuri, kokkuvõtja ja kokkuvõetava järkjärgulises taandumises lause tähendussisu tasandilt teksti või diskursuse tasandile ning tegevuse enda kivinemises diskursuse tasandi suhestajaks-märgiks: määrsõna märgib, et laiendatav lause või fraas (kui kokkuvõtmise tulemus) väljendab oma teema (kui kokkuvõtmise tegevusobjekti) seisukohast midagi olulist või lõplikku.

Kaassõna kokkuvõttes tarind järgib aga samakujulise põhisõnaga nimisõnafraasi lauselist üldfunktsiooni (sündmuste või tulemuste kontekstualiseerimine), kuid täidab ülesannet ökonoomsemalt, jättes arvesse võtmata nimisõnavormi semantilise tekstitähenduse ja keskendudes sisu seisukohalt põhilisele, (endise teksti) sündmuslikule või tulemuslikule sisule.

Artiklis jälgiti ühe keelendi(kogumi) kasutuses ilmnevate sõnaliikidevaheliste funktsionaalsete kokkupuudete põhjal keelendi grammatilisuse seost mõistelise tähendusega. Grammatilisema funktsiooniga keelendi puhul on mõisteline tähendus taandunud, kuid grammatiline funktsioon ise põhineb selsamal taandunud tähendusel. 


\section{Kirjandus}

Diewald, Gabriele 2011. Grammaticalization and pragmaticalization. - The Oxford Handbook of Grammaticalization. Eds. Heiko Narrog, Bernd Heine. Oxford University Press, 450-461. http://dx.doi.org/10.1093/oxf ordhb/9780199586783.013.0036.

EKG II = Mati Erelt, Reet Kasik, Helle Metslang, Henno Rajandi, Kristiina Ross, Henn Saari, Kaja Tael, Silvi Vare 1993. Eesti keele grammatika. II. Süntaks. Lisa: Kiri. Peatoim. Mati Erelt. Toim. Tiiu Erelt, Henn Saari, Ülle Viks. Tallinn: Eesti Teaduste Akadeemia Keele ja Kirjanduse Instituut.

EKSS = Eesti kirjakeele seletussõnaraamat. 1-6, 2009. „Eesti kirjakeele seletussõnaraamatu“ 2., täiend. ja parand. trükk. Toim. Margit Langemets, Rudolf Karelson, Mai Tiits, Tiia Valdre, Leidi Veskis, Ülle Viks, Piret Voll. Eesti Keele Instituut. Tallinn: Eesti Keele Sihtasutus.

Erelt, Mati 2014. Eesti keele lauseõpetus. Komplekslause. Tartu Ülikooli eesti keele osakond. Tartu: Tartu Ülikool.

Habicht, Külli 2000. Grammaticalization of adpositions in Old Literary Estonian. - Estonian: Typological Studies IV. Ed. Mati Erelt. (= Publications of the Department of Estonian of the University of Tartu 14.) Tartu: University of Tartu, 19-58.

Harder, Peter, Kasper Boye 2011. Grammaticalization and functional linguistics. - The Oxford Handbook of Grammaticalization. Eds. Heiko Narrog, Bernd Heine. Oxford University Press, 56-68. http://dx.doi.org/10.1093/ oxfordhb/9780199586783.013.0005.

Haspelmath, Martin 1995. The converb as a cross-linguistically valid category.Converbs in Cross-Linguistic Perspective. Structure and Meaning of Adverbial Verb Forms - Adverbial Participles, Gerunds. Eds. Martin Haspelmath, Ekkehard König. (= Empirical Approaches to Language Typology (EALT) 13.) Berlin: Mouton de Gruyter, 1-55.

Karelson, Rudolf 2005. Taas probleemidest sõnaliigi määramisel. - Eesti Rakenduslingvistika Ühingu aastaraamat 1 . Koost. Margit Langemets. Toim. Maria-Maren Sepper. Tallinn: Eesti Keele Sihtasutus, 53-70.

Kasik, Reet 2015. Sõnamoodustus. Toim. Katrin Kern. (= Eesti keele varamu I.) Tartu: Tartu Ülikooli Kirjastus.

Plado, Helen 2010. Eesti keele $d a$-infinitiivis öeldisverbiga tingimuslaused. Eesti ja soome-ugri keeleteaduse ajakiri 1-2, 255-272.

Plado, Helen 2015. The subject of the Estonian des-converb. - SKY Journal of Linguistics 28, 313-348.

Uuspõld, Ellen 1966. Määrusliku des-, mata-, nud-( nuna-) ja tud-( tuna-) konstruktsiooni struktuur ja tähendus. - Keele modelleerimise probleeme 1. (= Tartu Riikliku Ülikooli toimetised 188.) Tartu: Tartu Riiklik Ülikool, 1-196. 
Uuspõld, Ellen 2001. des- ja mata-vormide kaassõnastumine ja eesti komareeglid. - Keele kannul. Pühendusteos Mati Erelti 60. sünnipäevaks 12. märtsil 2001. Koost. ja toim. Reet Kasik. (= Tartu Ülikooli eesti keele õppetooli toimetised 17.) Tartu: Tartu Ülikooli Kirjastus, 306-321.

Veismann, Ann, Mati Erelt 2017. Määrsõnafraas. - Eesti keele süntaks. Toim. Mati Erelt, Helle Metslang. (= Eesti keele varamu III.) Tartu: Tartu Ülikooli Kirjastus. (Ilmumas.)

ÕS 2013 = Eesti õigekeelsussõnaraamat ÕS 2013. Toim. Maire Raadik. Koost. Tiiu Erelt, Tiina Leemets, Sirje Mäearu, Maire Raadik. Eesti Keele Instituut. Tallinn: Eesti Keele Sihtasutus.

Ylikoski, Jussi 2003. Defining non-finites: action nominals, converbs and infinitives. - SKY Journal of Linguistics 16, 185-237.

\section{Korpused}

etTenTen $=$ eestikeelsete veebilehtede korpus. http://www2.keeleveeb.ee/dict/ corpus/ettenten/.

$\mathbf{K K}=$ eesti kirjakeele korpus. http://www.cl.ut.ee/korpused/kasutajaliides/.

VAKK = Tartu Ülikooli vana kirjakeele korpus. http://www.murre.ut.ee/vakkur/ Korpused. 


\section{kokkuvõttes 'in summary' between different parts of speech}

\section{CARL ERIC SIMMUL}

There is an expression in Estonian which, written separately (kokku võttes) or together (kokkuvõttes), can cover four different parts of speech. The -des form of the phrasal verb, which expresses several different types of summarizing actions (e.g. eelnevat kokku võttes 'to summarize the foregoing'), and the inessive form kokkuvõttes of the noun kokkuvõte 'summary (text)' (lühikeses kokkuvõttes 'in a short summary') are paradigmatic forms of full words represented in dictionaries. In addition to these, however, there is also a postpositional usage (kolme etapi kokkuvõttes 'with the three stages taken all together') and an adverbial usage (kokkuvõttes võis rahule jääda 'in summary, one could be satisfied'). These latter two usages have not been listed in dictionaries.

This article examines the usage of kokkuvottes/kokku võttes in different parts of speech, using corpus data to identify the semantic and morphosyntactic features that determine part of speech and the boundary areas between usages corresponding to different parts of speech. These are regarded as possible historical bridging contexts, where the postposition and adverb have developed on the basis of the noun and/or the verb. The analysis of such borderline cases is based on semantics. As the expressions examined all originate from the phrasal verb kokku võtma 'to summarize', the usages corresponding to different parts of speech have a shared conceptual foundation and basis of comparison: an event of summarizing. In explaining the relationships between different parts of speech, the four components of this event are distinguished: 1) the act of summarizing, 2) the logical subject, 3) the logical object ja 4) the result of the summarizing activity.

The postposition kokkuvõttes can be analyzed as a grammaticalized noun form: it no longer connotes a text as the original noun form does, but its grammatical function is still based on the meaning of that noun form. The adverb kokkuvõttes, which has a broader scope of usage, has functional similarities with the -des construction and the postpositional construction, and, judging from analogous examples of adverbialized nouns, it is possible that this form has indeed derived from the noun. However, the most likely development path for the adverbial is based on the retreat of the summarizing action expressed in the -des construction and its argument structure from the level of sentence meaning to the level of text/ 
discourse. This explanation is supported by the existence of the graduated transition zone which joins the -des construction and the adverb even today.

Keywords: Estonian, syntax, morphosyntax, parts of speech, word meaning, grammaticalization, lexicalization

Carl Eric Simmul

Tartu Ülikooli magistrant

simmulman@gmail.com 